\title{
Yann Mortelette, Les Trophées oubliés
}

\section{Brenda Piselli}

\section{(2) OpenEdition}

\section{Journals}

\section{Edizione digitale}

URL: https://journals.openedition.org/studifrancesi/26672

DOI: 10.4000/studifrancesi.26672

ISSN: 2421-5856

\section{Editore}

Rosenberg \& Sellier

\section{Edizione cartacea}

Data di pubblicazione: 1 avril 2007

Paginazione: 205

ISSN: 0039-2944

\section{Notizia bibliografica digitale}

Brenda Piselli, «Yann Mortelette, Les Trophées oubliés», Studi Francesi [Online], 151 (LI | I) | 2007, online dal 30 novembre 2015, consultato il 23 novembre 2021. URL: http://journals.openedition.org/ studifrancesi/26672 ; DOI: https://doi.org/10.4000/studifrancesi.26672

\section{Questo documento è stato generato automaticamente il 23 novembre 2021.}

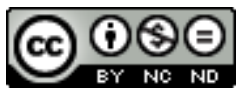

Studi Francesi è distribuita con Licenza Creative Commons Attribuzione - Non commerciale - Non opere derivate 4.0 Internazionale. 


\title{
Yann Mortelette, Les Trophées oubliés
}

\author{
Brenda Piselli
}

\section{NOTIZIA}

YANN MORTELETTE, Les Trophées oubliés , «Revue d'Histoire Littéraire de la France», 106e année, n. 3, juillet 2006, pp. 695-707.

1 L'A., in occasione della recente acquisizione di Fleurs de feu. Odes et sonnets di José-Maria de Heredia (Biblioteca dell'Arsenal, ms. 15466), analizza Les Trophées (1893) di Heredia, una raccolta di centoventi sonetti e due poesie. Dopo aver sottolineato l'importanza di quest'opera inedita, la quale spinge a riesaminare le composizioni che lo scrittore prima e gli editori successivi poi hanno trascurato, MORTELETTE fa emergere i criteri di selezione che hanno conferito ai Trophées la loro particolare fisionomia. L'A. rileva inoltre il lirismo parnassiano delle Fleurs de feu e l'influsso esercitato su Heredia da Leconte de Lisle, dai Classici latini (Catullo, Orazio, Marziale, Persio), dall'araldica e, per la struttura dell'opera, il metro e la figura-guida, dall'Inferno di Dante (Dante è la guida di Heredia nell'aldilà, come Virgilio fu quella di Dante). 